\title{
1. Congressional control of state taxation: evidence and lessons for federalism theory
}

\section{Brian Galle*}

\section{INTRODUCTION}

Theories of the "political safeguards" of U.S. federalism have frequently been aired but seldom tested. The basic claim, beginning with Wechsler (1954), is that state influence is sufficient to preserve state autonomy from federal encroachments. For example, Kramer (2000) argues that the dependence of federal officials on state party support gives state officials bargaining leverage to fend off incursions (see also Choper 1980, La Pierre 1985, Rubin \& Feeley 1994, Dana 1995). Critics counter that state autonomy as a whole is a public good, such that officials may have little incentive to exercise whatever influence they hold, and so only courts can adequately ensure that states in the long run will retain independence from federal control (Derthick 1986, Baker \& Young 2002, McGinnis \& Somin 2004). ${ }^{1}$ Others accept Wechsler's and Kramer's claims only partially, arguing that one or more of the branches of federal government are more or less apt to respect state autonomy (Mendelson 2004, Nzelibe 2006, Metzger 2008, Sharkey 2008, Pursley 2010).

In a parallel debate, commentators also disagree over which federal institution should be responsible for ensuring a free flow of trade among the states. In the current U.S. arrangement, courts and Congress share power, with Congress holding final say. Courts fill in interstitially, striking

* The author gratefully acknowledges helpful comments from Wally Hellerstein, John Kincaid, Jon Klick, Rob Mikos, Austin Nichols, Larry Ribstein, Scott Taylor, Samantha Zyontz, and attendees of presentations at the American Law \& Economics Association, the Conference on Empirical Legal Studies, and George Washington University Law School.

For extended discussion of this argument and exploration of the instances in which autonomy would not represent a public good, see Galle \& Seidenfeld (2008) and Galle (2008). 
down sub-national taxes and regulations that discriminate against interstate commerce. Since at least the 1950s, however, the Court has urged Congress to assume more responsibility for reviewing state taxation. In recent decades the Court has seemed to take steps to force Congress to do so. And prominent scholars have suggested retreat from or wholesale abandonment of federal judicial oversight of state taxes (Redish \& Nugent 1987, Zelinsky 2002).

This chapter breaks from the existing literature by offering quantitative evidence of how Congress has actually used its authority to regulate state taxing power. ${ }^{2}$ Utilizing a hand-collected dataset of every federal statute affecting state power to tax since the beginning of the republic - though only a handful predate the 20th century-I analyze what features, conditional on enactment, characterize congressional behavior in this area. I find that when Congress acts, it tends to reduce rather than expand

2 Several earlier authors examine the evidence on the safeguards hypothesis, but their efforts are purely qualitative, generally consisting of the historical background of one or two statutes (Lee 1988, Dinan 1997, Hamilton 2001, Pickerill 2004, Jones 2004, Resnik 2008, Dinan 2009). Bowman \& Krause (2003:302) lament this state of affairs. Frymer \& Yoon (2002) also present qualitative descriptions of the sources of funding for modern political parties, which they argue bears on the Kramer hypothesis. Jenkins \& Roscoe (2014) find evidence that local party activity affects national party success, a key assumption of the political safeguards theory, but they do not connect these findings to congressional behavior. Kam and Mikos (2007) present a quantitative study of voter attitudes towards federalism, but similarly do not observe legislative outcomes. There is a somewhat more extensive literature examining the determinants of judicial federalism decisions (e.g., Cross \& Tiller 2000, Joondeph 2003, Solberg \& Lindquist 2006, Collins 2007); this chapter can be thought of as a congressional complement to those studies.

Perhaps the closest to an antecedent quantitative study is Nicholson-Crotty (2008), who reports that Congress proposes and enacts fewer pieces of stateautonomy-affecting legislation during election years. However, Nicholson-Crotty does not examine whether legislation is simply shifted from one year to another, so that his findings appear to speak only to the timing, rather than the volume, of congressional action. His results can be equally well explained by two competing hypotheses. On the one hand, legislation may decrease because of heightened state influence during crucial periods. Alternatively, federalism-type legislation may decrease because of opportunity costs: federalism legislation is less important, and creates fewer rents, than others, and so is shifted aside when stakes are higher. Only the first of these would support the political-safeguards hypothesis.

I do not mean to suggest that quantitative analysis is necessarily superior to qualitative efforts. Indeed, the quantitative analysis here necessarily must omit important details that may be critical to the outcome of any particular piece of attempted legislation. The point is only that this contribution differs from the existing literature in its wider focus on the commonalities across statutes. 
state autonomy, except in the case of state power to tax Indian tribes and tribal resources. I also find that public-choice factors appear to play a significant role in congressional decisions: narrow, concentrated interests are considerably more likely to win relief from state taxes. Surprisingly, this tendency holds true even when there are potentially competing concentrated interests, although competition somewhat blunts the efficacy of special interests.

These findings arguably weigh against wholesale judicial retreat in both of the areas I have mentioned. On the state autonomy front, I cannot observe the statutes that failed to pass, so I cannot draw strong conclusions about whether "political safeguards" may suffice to defeat legislation in some or even most instances. I can, though, confirm empirically the theoretical prediction that safeguards are unlikely to be fully effective in the face of strongly opposed congressional self-interest. Prior qualitative observations of federal lawmaking have noted many instances where federal authority has appeared to expand but has not generally inquired whether these expansions might serve to enhance state autonomy in the long run. My quantitative approach allows me to control, to some extent, for that possibility, and so I argue that my evidence represents a useful advance over the current state of the literature.

In this respect I may provide support for current judicial practices, which allow many forms of congressional regulation of states but prohibit certain so-called "unfunded mandates." Likewise, it is a familiar point in the theoretical literature that political economy factors may lead to excessive federal legislation if the federal government is not obliged to incur significant costs for its decisions. (La Pierre 1985). In that situation, enacting or threatening legislation allows the federal actor to extract rents, but the costs of the legislation are largely externalized. My results help to confirm this pattern: when Congress regulates state taxation, it tends to enact statutes that pass costs on to others (i.e., reduce state taxing authority) while generating rewards for itself (taking credit for enacting a tax cut).

On the free-trade front, my evidence again casts some doubt on the wisdom of placing full authority in the hands of an unrestrained Congress. Here my own hypotheses were that Congress is a dubious caretaker of state taxing power, for two reasons. For one, as I have just explained-although the literature has not fully recognized it - congressional regulation of state taxes has exactly the political-economy structure of an unfunded mandate. For another, Congress and the States arguably compete over the same tax base, meaning that any reduction in state authority potentially results in less political resistance to congressional revenue-raising.

These hypotheses are not mutually exclusive, and indeed I find support for both. Again, I find that opportunities to extract rents from concentrated 
interest groups correlate highly with enactment of federal legislation reducing state taxing power. As for the second hypothesis, I note that Indian tribes and Indian tribal lands are, as the Constitution states, "not taxed" by the federal government. Congress therefore does not compete with the States for the opportunity to tax them. I find, accordingly, that Congress is considerably more permissive in its treatment of state efforts to tax the tribes, although I cannot entirely rule out the possibility that tribes are simply much worse than anyone else at lobbying Congress.

Part I of the chapter provides a brief overview of the legal context for my investigation. Part II reviews the prior literature, and offers several hypotheses about the expected dynamic between states and the Congress that regulates them. Part III explains my methodology, and Part IV reports the results. Part V offers interpretation and caveats.

\section{LEGAL FRAMEWORK FOR FEDERAL CONTROL OF STATE TAXES AND TRADE}

The U.S. Constitution grants overlapping taxing authority to states and the federal government. On the face of the Constitution the states' power is plenary, aside from bars on tariffs on imports and exports, and "dut[ies] of tonnage." The text also suggests that the federal government's taxing power is virtually unlimited, although until the enactment of the 16th Amendment in 1913 it imposed the burdensome procedural hurdle that all "direct" taxes had to be apportioned; "income" taxes now are exempt from that requirement. One other notable federal restriction is that the Constitution suggests that "Indians [are] not taxed" by the national government (U.S. Const. Art. I $§ 2$ ).

At the same time, both courts and Congress have used federal authority to protect free trade among the states to modify state taxing power. Congress, of course, can "regulate Commerce ... among the several states, and with the Indian Tribes" (U.S. Const. Art. I $\S 8 \mathrm{cl} .3$ ). It has often used this power to alter the scope of state authority. For example, in ERISA, the Employee Retirement and Income Security Act of 1974, Congress invoked national uniformity to sweep aside all subnational regulation of employee benefit plans, including any efforts to tax such plans or their assets.

Even when Congress has stood still, the Supreme Court has defended free trade against perceived state threats. Beginning with Chief Justice Marshall's opinion striking down New York regulation of steam boats, in Gibbons v. Ogden, the Court has interpreted the constitutional grant of the power to regulate "Commerce" as also impliedly requiring a common 
economic market among states free of unnecessary state burdens. Most lawyers refer to this judicial enforcement of free-trade principles as the "dormant" commerce clause, following a coinage of one of the early 19th-Century cases (Willson v. Black Bird Creek Marsh Co., 27 U.S. (2 Pet.) 245 (1829)). Congress, however, can authorize any judicially-suspect state action if it so chooses (see Metzger 2007 for more discussion).

Similarly, for much of the 19th and early 20th centuries federal courts presumed that the federal government was immune to taxation by the states. This immunity extended, at its high-water mark, even to the salaries of contractors working for the federal government. Even then, though, immunity was waivable by Congress. But this immunity doctrine waned beginning in 1936, and today extends only to entities that are functionally indistinguishable from the federal government itself.

Much as with federal instrumentalities, Indian tribes have long been held to be presumptively beyond the reach of taxation both for the states and also for the federal government. The status of transactions between tribes and outsiders, of outsiders conducting business on Indian land, and of individual native Americans, has been less clear and remains a source of some legal uncertainty. For example, the U.S. Treasury ruled in the 1930s that, while tribes themselves were not subject to the federal corporate income tax, individual members were responsible for paying their own federal income and social security taxes. Congress, however, may authorize states to tax transactions occurring in Indian territory, apparently including profits inuring directly to tribes, and modern doctrine permits states to collect many general taxes, such as cigarette excises, within Indian lands even in the absence of express authorization. ${ }^{3}$

I exploit the variations among and within these different legal regimes in an effort to identify trends in how Congress exercises its power to regulate state taxing authority, as I now will detail.

\section{HYPOTHESES}

The basic research question for this study is to examine how Congress has employed its authority to curtail states revenues: has it been a bully, a defender of national interests, an indifferent by-stander, or a sell-out? The existing literature offers several competing hypotheses about how Congress will behave. Roughly speaking, they run the gamut from

3 For more discussion of this complex area, see Frickey (1990), Taylor (2007), and Jensen (2008). 
predicting that Congress will seek to maximize national welfare to predicting that it will instead maximize the rent-seeking opportunities of individual members of Congress. These hypotheses come from different strands of the legal, economic, and political science literatures, and have not been fully synthesized before, so that some discussion is warranted.

The most optimistic assessments come directly from judicial decisions applying the dormant commerce clause and the bulk of the legal commentary on them. Courts and commentators alike observe that the fundamental flaws the Constitution was designed to solve were that state decisions affecting interstate trade gave rise to externalities, and that Coasean interstate bargaining was fraught with coordination difficulties (e.g., Tribe 1999). As a nationally representative body, Congress is supposed to internalize all nationwide costs and benefits.

According to the literature, federal courts, too, can play this internalization role, but the contemporary trend is to prefer Congress. The judicial role was justified, most famously by Justice Jackson, as a necessary supplement to Congress in a large nation whose Constitution was designed to make national legislation difficult. But modern decisions and commentary emphasize instead the putatively superior democratic pedigree and factfinding abilities of Congress (Hellerstein 1941, Eule 1982, Swain 2003). Some important voices, including Justice Thomas, have called for complete abandonment of the dormant commerce clause and a full takeover by Congress (Redish \& Nugent 1987, Zelinsky 2002; Eule 1982 opposes the dormant commerce clause but would retain some role for judges).

There have been very few skeptics in the other direction. Shaviro (1992) and Galle (2007a) observe that Congress is not necessarily a nationallyrepresentative body. Instead, of course, its members serve a regional constituency, and it is only by bargaining, log-rolling, and other coordination mechanisms that its outcomes approximate some national interest. Basic free-rider theory suggests, then, that issues of general importance to the states will not garner a devoted congressional following, while issues that disproportionately affect one or a few regions will have strong supporters who cannot expect to free ride on the efforts of others. Voters who are concerned about division of power between tiers of government cannot generally punish the national government as a whole when it overreaches (Bednar 2007). Thus, the prediction would be that Congress will often enact, or at least overlook, measures that allow some states to burden the rest (Galle 2007a).

In a related vein, turning from the dormant commerce clause to the broader field of federalism theory generally, many commentators point to public-choice factors that would likely tend to lead members of Congress to neglect national welfare-maximization in favor of self-interest. For 
example, Zelinsky (1993) and McGinnis and Somin (2004) point out that to the extent that political autonomy for lower-tier governments improves long-term national welfare, that gain is a public good for the nation as a whole. We therefore should expect defenders of state autonomy to free ride on one another, so that state autonomy tends to lose out to the preferences of concentrated interest groups in political struggles. ${ }^{4}$ Similarly, Mayhew (1974) predicts that federal restrictions may be imposed to appease special interests, and Macey (1986) predicts that members of Congress will assert exclusive federal power over some policy areas in order to monopolize rents from the regulated industries.

In other instances Congress may share power in order to pass along costs but retain credit. That is the standard explanation for the popularity of so-called "unfunded mandates," in which Congress enacts policies but requires state governments to carry them out (Zelinsky 1993, Garrett 1997). The costs of implementation, and potentially the political blame for policy failures, can be passed on to others (see Bednar 2007 for a formal model). Critics argue that unfunded mandates are likely welfare reducing because Congress does not internalize the costs of its decisions (LaPierre 1985). ${ }^{5}$

It might be argued that internalization is not an important consideration because members of Congress are relatively insensitive to cost. Of course, to the extent that Congress is motivated by non-budgetary factors, the importance of budget internalization diminishes (Dana 1995, Levinson 2005), but would still be significant on the margin. Levinson (2005:928-9) goes further, arguing that members of Congress are at best only weakly motivated by the size of the federal budget, since the effect of any one actor on the budget as a whole is largely an externality for individual members. If so, we would expect that budgetary factors will be more predictive for smaller legislative bodies, since in that case the externality is smaller and Coasean bargaining over externalities somewhat more straightforward.

4 For more general assertions of the superiority of the executive in maximizing national welfare, see Olson (1982), McGinnis (2001) and Kagan (2001).

5 In addition to curtailing "excess" federal legislation, however that concept might be defined, internalization serves another important federalism function by preserving state power to bargain with the federal government. As Hills (1998) explains, when Congress must pay states for their agreement, or must pay for the administrative apparatus to enforce its laws in the absence of state cooperation, states gain some hold-up power. Arguably, this heightened bargaining power increases state autonomy, although in instances in which individual hold-outs are an impediment to collective action, this power may be counter-productive. See Galle (2008) and Bulman-Pozen and Gerken (2009) for more extensive discussions of this latter point. 
While these observations are now commonplace in the general federalism literature, they have not generally been applied to the question of the dormant commerce clause. Indeed, a leading proponent of exclusive congressional control over free trade has also been a significant critic of unfunded mandates (compare Zelinsky 1993 with Zelinsky 2002). Yet a congressional decision to prohibit certain state taxes would appear to have a similar political structure to other unfunded mandates: the state loses money, while Congress can take political credit with the affected interest group.

Of course, the claim that Congress does not internalize the costs of imposing mandates on states, or of otherwise reducing state authority, assumes that state officials have no way of influencing their federal counterparts (Adler 1997). In fact, though, there is a robust tradition in the legal literature arguing that state officials have powerful sway, such as through their ability to provide get-out-the-vote support during federal elections (Kramer 2000; for a skeptical treatment of these claims, see Schleicher 2016). Alternatively, in the modern regulatory state in which many programs are vertically integrated between the States and the federal government, states have hold-out power; they can refuse to provide the information and on-the-ground enforcement that federal programs depend on (Bulman-Pozen and Gerken 2009). Or, in the case of federal law that is enacted as a condition attached to a federal grant, states can simply refuse to accept the conditional funds.

The extent of state influence is likely to be contingent on institutional arrangements and other factors. For instance, hold-out power depends on whether states in fact have any real leverage: refusal to accept a conditional grant is a more meaningful threat if the federal government lacks constitutional authority to enact the grant's conditions outright (Galle 2004). To take another example, some scholars have argued that state-official lobbying is not a meaningful constraint on Congress' ability to curtail state prerogatives because of free riding among those officials (Derthick 1986, Baker \& Young 2002, McGinnis \& Somin 2004). Bellia (2006) presents a nice case study of this effect, finding that federal regulation of the power of state courts to hear civil suits was facilitated by the fact that the legislation offered concentrated benefits for interstate businesses while diminishing the power of most states uniformly. But in some cases state resistance to federal law may be more like a private good to the official, such as when there is local interest-group pressure in opposition (Levinson 2005, Galle 2008).

Putting together these various political-economy observations, we should expect that Congress will be especially apt to reduce state authority when several factors coincide. If members of Congress can extract rents 
from a concentrated interest group, if Congress faces little opportunity cost in enacting legislation, if the states have no hold-up opportunities, and if the state interests affected are shared widely and similarly by most states, we should expect the effectiveness of the "political safeguards" of state lobbying and other influence to be at its nadir. Many of these factors occur with great frequency in the federal regulation of state taxing authority.

Competition for revenues, a factor not mentioned elsewhere in the literature, also warrants some attention. Other commentators have often assumed that overlapping taxing authority shared by two sovereigns leads to crowding out: citizens are willing to tolerate only so much taxation, and so higher taxes by one government are said to put pressure on the other to reduce its own revenues (e.g., Baker 1995). Brennan and Buchanan (1984) go so far as to argue that a shared tax base is a common pool that overlapping sovereigns race to fish from. This competition theory is at least as old as Hamilton, who discussed it in the federalist papers, and Madison, who thought that vertical competition between the States and the federal government would restrain the size of both. And normatively, overlapping tax bases are arguably inefficient to the extent that they increase the total marginal rate facing economic actors, and therefore increase the deadweight loss of taxation, an effect that is likely an externality for each of the overlapping levels (Hanson \& Stuart 1987; see Klick \& Parisi 2005 for a formal model).

It is not clear that crowd-out in fact happens, or that it is normatively undesirable, but it is certainly a piece of conventional wisdom (for evidence, see Galle 2013). Overlap also has benefits, such as reduced compliance costs for citizens and the opportunity for economies of scale and scope for governments (Galle 2007b). Descriptively, recent evidence suggests citizens may not consider one level of tax when making political decisions about the other (McCaffrey \& Barron 2006). Nonetheless, courts and politicians have long assumed that taxation at one level threatened the ability of the other sovereign to tax the same base. For example, crowdout was the Supreme Court's asserted basis for constitutional limits on state taxing power in the mid-19th Century, was one of the Court's recent justifications for limits on federal conditional spending (Nat'l Federation of Indep. Bus. v. Sebelius, 567 U.S. _, 132 S.Ct. 2566, 2662 n.13 (2012)) and was the main rationale offered by Congress in 1963 for the federal income-tax deduction for state and local taxes paid.

In any event, to the extent that Congress is motivated by budgetary pressures and believes that crowd-out is a possibility, we should expect that Congress is not a fully trustworthy custodian of state taxing power. Just as Congress may use its preemption power to monopolize 
opportunities for political rents, so too might it use the commerce power to control the tax base.

As a result, I hypothesize that when Congress acts to alter state authority to tax, it will tend to reduce that power rather than expand it. I expect that to be particularly true in the instance where the tax at issue falls on a narrow interest, while the budget burden of repeal would fall equally on most or all state budgets. If my predictions are incorrect, though, that finding would strengthen considerably the argument of those who claim that the political safeguards of federalism are sturdy in all contexts.

\section{METHODOLOGY}

In order to test these hypotheses, I compiled a dataset consisting of every statute enacted by the U.S. Congress affecting state taxing power. I then coded each statute for a variety of factors relating to my hypotheses, and conducted regression analysis to test those theories. ${ }^{6}$

The dataset was drawn from a keyword search on HeinOnline's "U.S. Statutes at Large" database. ${ }^{7}$ I found HeinOnline's search function to be somewhat unreliable, returning slightly different results at different times with identical searches. However, at the time of this writing HeinOnline is the only searchable database of year-by-year statutory text extending back to the 19th Century. I ran the search repeatedly and cross-checked the results against one another to be certain I had found every statute.

Next, I attempted to identify for each statute a prior authority affecting the same form of state tax, such as an earlier statute or Supreme Court decision. This was important to the study for two reasons. First, I am interested primarily in how Congress changed what the states could do, because the direction of change offers better evidence about how Congress behaves. For example, if Congress enacts a statute that leaves state taxing power heavily constricted, but the law in place before was even stricter, I think that represents a victory for states, and vice-versa. Thus coding only the end result, and not the change from baseline, could produce misleading results. Second, and relatedly, the extent of pre-existing restrictions at the time of enactment is potentially important for hypothesis-testing; we

6 A Statutory Appendix with a complete listing of statutes, prior authorities, and scores is available from the author upon request.

The search was "tax* state*" $\sim 15$ OR "tariff* state*" $\sim 15$ OR "levy state*" $\sim 15$ OR "impost* state*" $\sim 15$ OR "excise* state*" $\sim 15$ NOT treaty. The search returned 976 hits, of which 116 proved to be related to state taxing power. 
have to control for the possibility that existing law might influence states' ability to affect federal legislation.

I then coded both the statutes and the corresponding prior authorities. I coded statutes for both their absolute and relative-to-baseline constraints on state power, while the prior authorities were coded only for absolute scores. Both categories were coded on a scale of one to seven. For the absolute score, a "one" represented a complete prohibition on a major source of state revenues, while a "seven" was no restrictions. For relative scores, a "four" was no change relative to baseline, while "one" was a severe narrowing and "seven" was major expansion of the States' authority. I employed three research assistants to assist with coding, and independently coded each statute and authority without looking at the assistants' scores; where opinions ended up differing I used the average of the scores, weighting my own twice as heavily.

Alternatively, I also report regression analyses in which I code no change as zero, new constraints as -1 , and new expansions of state taxing authority as 1 . While I believe that coding scores over a wider range allows me to exploit additional information available in the sample, I recognize that there may also be increased subjectivity in the coding of the degree rather than simply direction of change. My results are robust to the use of this alternative measure.

Before proceeding with additional coding, I dropped from the dataset 30 statutes that lacked a prior authority, leaving 85 observations, nearly all from the 20th and 21 st Centuries. The reasoning for dropping observations with no prior authority was that by default state taxing power (other than power to tax Indian tribes) is unlimited; therefore, in the absence of any prior reduction in state authority, the only direction for Congress to go would be down. That, of course, would have prevented us from drawing meaningful inferences from any finding that Congress tended to reduce state power. So I instead confined my analysis to statutes in which Congress had an opportunity either to further constrain states or instead to undo the prior restraints. Editing the data in this way does raise some interpretation questions of its own, as I will discuss further in Part V.

Finally, I coded for additional aspects of my hypotheses I wished to test. I created a dummy variable for each statute reflecting its fit with basic public-choice factors: if the state tax affected had burdened a relatively concentrated interest group, but its budget effects were shared widely within states and across states, I coded that statute a " 1 " in the public choice category. I also added a dummy variable, called "rival," which was coded " 1 " when the congressional enactment in question would also place another concentrated interest group at a competitive disadvantage. For 
example, Public Law 86-272, which restricts state sales taxes on remote sales, was coded " 1 " in both categories, because it favored out-of-state distributors over local retailers.

In an effort to tease apart the public-choice and base-competition hypotheses, I also compared statutes regulating state efforts to tax Indian tribes (and, before 1934, individual Native Americans) with all others. Congress does not and has never taxed the tribes directly, and arguably the Constitution prohibits them from doing so. Until the 1930s it was assumed that members of tribes, too, were exempt from federal tax, but the Treasury ruled otherwise and that ruling has apparently been followed ever since. Thus, I expect that competition for the opportunity to tax the Indian tribes is considerably less intense than other forms of taxation. Accordingly, I created a dummy variable to indicate statutes affecting "Indians not taxed" by the federal government. Where there was legal uncertainty whether Congress could tax the affected source of revenue, I coded the enactment " 0 ," on the view that this was the assumption most contrary to my hypothesis of differential treatment. Of the 85 observations, 20 of them were coded " 1 " for statutes affecting untaxed tribes.

I test Levinson's theory about the insensitivity of Congress to its own budget in several ways. My Indian variable sheds light indirectly on that question, since one possible explanation for more generous treatment of state laws affecting the tribes is that Congress is less concerned with its own revenues in that instance. A more direct measure I employ is to include the log of the number of members of the House of Representatives as an explanatory variable. ${ }^{8}$ Again, if members of Congress treat the budget as a common pool, a smaller pool should result in greater cost internalization. And, finally, I include measures of slack or strain in the federal budget, such as annual debt or surplus as a percentage of GDP.

The statistical analysis took several forms. I performed a simple f-test to estimate the mean relative score within the restricted data set, and also performed that test separately for Indian and non-Indian statutes. Due to the small number of Indian statutes, I could not perform a chi-square test to compare the two. I did, however, include the Indian dummy variable in a series of regression analyses.

Because OLS is unbiased for ordered rankings, I estimate results

8 I do not report results for the number of Senators because of the small variation in that variable in the sample. I do find significant results for Senate membership when it is included in the regressions, but those results appear to be driven almost entirely by three extreme outlier observations from the 19th Century. 
Table 1.1 Descriptive statistics

\begin{tabular}{|c|c|c|c|c|c|}
\hline Variable & Obs & Mean & Std. Dev. & Min & Max \\
\hline public choice & 85 & .4705882 & .5020964 & 0 & 1 \\
\hline Indian & 85 & .2588235 & .4405878 & 0 & 1 \\
\hline year & 85 & 1960.882 & 33.70545 & 1864 & 2007 \\
\hline efficient? & 85 & .2705882 & .4469003 & 0 & 1 \\
\hline coordination? & 85 & .2823529 & .4528157 & 0 & 1 \\
\hline rival & 85 & .2941176 & .4583492 & 0 & 1 \\
\hline absolute score & 85 & 4.423529 & 1.257136 & 2 & 7 \\
\hline relative score & 85 & 3.835294 & 1.213486 & 1 & 6 \\
\hline $\begin{array}{l}\text { prior authority } \\
\text { score }\end{array}$ & 85 & 4.364706 & 1.502752 & 2 & 7 \\
\hline surplus per gdp & 85 & -2.391176 & 3.891649 & -22.7 & 2.4 \\
\hline house members & 85 & 427.1765 & 34.61701 & 184 & 437 \\
\hline $\begin{array}{l}\text { percent dem } \\
\text { house }\end{array}$ & 85 & .5566555 & .0948279 & .3011494 & .7402299 \\
\hline senate seats & 85 & 97.24706 & 6.502574 & 52 & 100 \\
\hline $\begin{array}{l}\text { percent dem } \\
\text { senate }\end{array}$ & 85 & .5439583 & .1022101 & .1923077 & .7395833 \\
\hline $\begin{array}{l}\text { house med } \\
\text { dim. } 1\end{array}$ & 85 & .0224471 & .1798338 & -.255 & .414 \\
\hline $\begin{array}{l}\text { house med } \\
\quad \operatorname{dim} .2\end{array}$ & 85 & .0111529 & .0885928 & -.135 & .23 \\
\hline $\begin{array}{l}\text { h maj party } \\
\text { med } 1\end{array}$ & 85 & -.0226824 & .3523874 & -.388 & .526 \\
\hline $\begin{array}{l}\mathrm{h} \text { maj party } \\
\text { med } 2\end{array}$ & 85 & .1227882 & .1792056 & -.369 & .53 \\
\hline sen med dim. 1 & 85 & -.0336941 & .1290925 & -.301 & .318 \\
\hline sen med dim. 2 & 85 & -.0389765 & .1004343 & -.303 & .162 \\
\hline $\begin{array}{l}\text { sen maj party } \\
\text { med } 1\end{array}$ & 85 & -.0097765 & .3301069 & -.502 & .459 \\
\hline $\begin{array}{l}\text { sen maj party } \\
\text { med } 2\end{array}$ & 85 & .0287882 & .2503121 & -.462 & .33 \\
\hline
\end{tabular}

utilizing both OLS and an ordered probit. ${ }^{9}$ A probit model assumes a normal underlying distribution; however, the literature advises against use of heteroskedasticity-corrected ordered probit in models with fewer

9 I also utilized an ordered logit, which (once adjusted for the expected differences in coefficients between a probit and logit model) resulted in similar predicted marginal results as the ordered probit. As a result, I do not report the ordered logit findings. 
than 100 observations (Keele \& Park 2006). Therefore I limit use of the probit model to serving as a double-check on the accuracy of the OLS regressions. ${ }^{10}$

I estimate a series of regressions using relative change in restrictions as the dependent variable. To test several aspects of my hypothesis, described in more detail in the "Interpretation and Caveats" section, I constructed indicator variables for whether a given statute could plausibly be described as efficiency-enhancing under conventional microeconomic analysis, and for whether it resolved coordination problems among the states. I further control for year, absolute score of prior authority, ideological composition of the two houses of Congress, ${ }^{11}$ and, where available, popular attitudes towards the federal government, federal taxation, and taxes in general. ${ }^{12}$ I measure congressional ideology using historical DW-nominate scores calculated by Carroll et al. (2011). ${ }^{13}$ I include measures for both the median position of the majority party as well as for Congress as a whole.

Thus, the OLS regressions estimate the equation:

$$
\begin{aligned}
R_{i}= & \alpha+\beta_{1} \text { Public Choice }_{i}+\beta_{2} \text { Rival }_{i}+\beta_{3} \text { Public Choice }_{i} * \text { Rival }_{i}+\beta_{4} \text { Efficient }_{i}+ \\
& \beta_{5} \text { Coordinate }_{i}+\beta_{6} X i+C_{i}
\end{aligned}
$$

\section{RESULTS}

My findings provide support for both the public choice and tax-base competition hypotheses. When Congress acts, it tends to reduce state

10 Unlike the ordered probit, OLS assumes that the "width" of the bins counted is uniform. However, the "cut" point estimates in the ordered probit model are relatively evenly dispersed, except at the very top of the 1 to 7 range where there are few observations. This further supports the use of OLS.

11 Because prior literature suggests that Democrats have a lower propensity to vote for "states' rights" legislation (Hero 1989, Weissert \& Schram 1996), I also alternatively employed measures of the percentage of democrats in the House and Senate. Neither measure was significant and I do not report those results.

12 These latter controls were available only from the 1970s on, and because they proved insignificant, I do not report them.

${ }_{13}$ DW-nominate provides estimates of two different forms of congressional ideology. The first dimension "can be interpreted in most periods as government intervention in the economy" (Carroll et al. 2011). The second reflects views on civil rights and race relations. For discussion of how DW-nominate is computed, see Carroll et al. (2008). 
taxing power, and this effect is more pronounced where there is tax-base competition and where public choice theory predicts.

Even a casual inspection of the data suggests significant support for the base competition theory. The mean change in restrictions is in the more restrictive direction for non-Indian statutes, and is in the less-restrictive direction for Indian statutes, see Figures 1.1 and 1.2 below. An f-test indicates that the mean relative score for non-Indian statutes is 3.51 , with a 95 percent confidence interval of 3.23 to 3.79 - statistically significantly

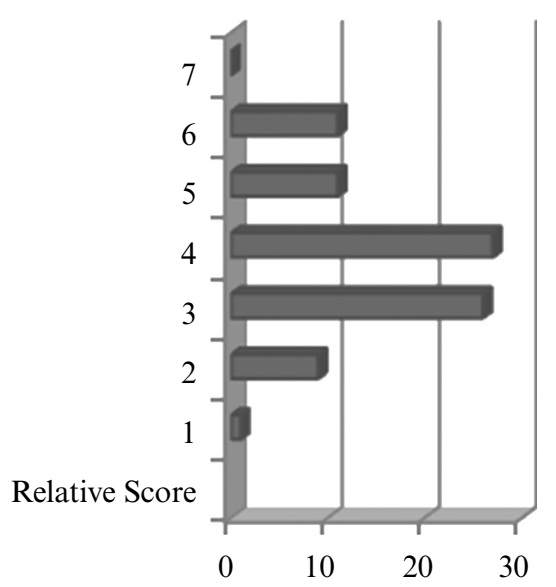

Figure 1.1 Relative scores for statutes affecting Indian tribes

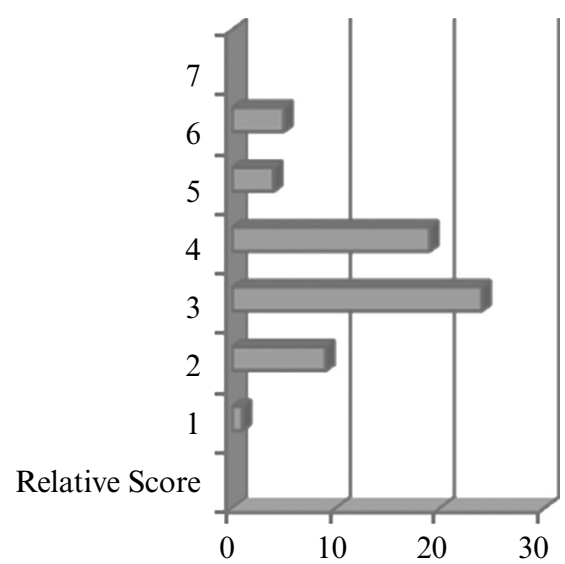

Figure 1.2 Relative scores for all non-Indian statutes 
different from the null hypothesis of 4 , no change. The mean relative score for Indian statutes is 4.70 , with a 95 percent confidence interval from 4.39 to 5.00 - again, significantly differing from 4 , but in the opposite direction.

Turning to the regression analysis, I find strong support for the publicchoice hypothesis in the form of a large negative coefficient for the public choice variable, as reported in Table 1.2 below. In other words, when

Table 1.2 Determinants of relative change in restrictiveness

\begin{tabular}{|c|c|c|c|c|}
\hline & $\begin{array}{c}\text { Range } 1 \text { to } 7: \\
\text { OLS }\end{array}$ & $\begin{array}{l}\text { Range } 1 \text { to } 7 \text { : } \\
\text { Ordered Probit }\end{array}$ & $\begin{array}{c}\text { Range }-1 \text { to } 1: \\
\text { OLS }\end{array}$ & $\begin{array}{l}\text { Range }-1 \text { to } 1 \text { : } \\
\text { Ordered Probit }\end{array}$ \\
\hline Public Choice & $\begin{array}{l}-\mathbf{0 . 8 4 4} * * * \\
(0.232)\end{array}$ & $\begin{array}{l}-\mathbf{1 . 3 8 5} * * * \\
(0.399)\end{array}$ & $\begin{array}{l}-\mathbf{0 . 6 8 3} * * * \\
(0.172)\end{array}$ & $\begin{array}{l}-\mathbf{2 . 2 0 0 * * *} \\
(0.558)\end{array}$ \\
\hline Indian & $\begin{array}{l}\mathbf{0 . 6 4 7 * * *} \\
(0.209)\end{array}$ & $\begin{array}{l}1.010^{* * *} \\
(0.344)\end{array}$ & $\begin{array}{l}\mathbf{0 . 4 9 7 * * *} \\
(0.170)\end{array}$ & $\begin{array}{l}1.460 * * * \\
(0.435)\end{array}$ \\
\hline Rivals & $\begin{array}{l}-0.246 \\
(0.329)\end{array}$ & $\begin{array}{c}-0.343 \\
(0.422)\end{array}$ & $\begin{array}{l}-0.245 \\
(0.194)\end{array}$ & $\begin{array}{l}-0.626 \\
(0.495)\end{array}$ \\
\hline Surplus/GDP & $\begin{array}{c}-0.035 \\
(0.029)\end{array}$ & $\begin{array}{l}-0.073 \\
(0.052)\end{array}$ & $\begin{array}{c}0.001 \\
(0.019)\end{array}$ & $\begin{array}{l}-0.026 \\
(0.073)\end{array}$ \\
\hline Log house size & $\begin{array}{l}\mathbf{2 . 2 5 0}^{* * * *} \\
(0.797)\end{array}$ & $\begin{array}{r}3.185^{*} \\
(1.764)\end{array}$ & $\begin{array}{l}\mathbf{2 . 1 4 3}^{* * *} \\
(0.565)\end{array}$ & $\begin{array}{l}\mathbf{6 . 9 8 7 * *} \\
(2.837)\end{array}$ \\
\hline Rivalxpubchoice & $\begin{array}{c}0.612 \\
(0.558)\end{array}$ & $\begin{array}{l}0.823 \\
(0.593)\end{array}$ & $\begin{array}{l}\text { 0.609** } \\
(0.305)\end{array}$ & $\begin{array}{l}\mathbf{2 . 1 2 0}^{* * *} \\
(0.788)\end{array}$ \\
\hline Efficiency & $\begin{array}{l}\mathbf{0 . 7 3 3}^{* *} \\
(0.342)\end{array}$ & $\begin{array}{l}1.112 * * * \\
(0.355)\end{array}$ & $\begin{array}{l}\mathbf{0 . 4 8 1} * * \\
(0.187)\end{array}$ & $\begin{array}{l}\mathbf{1 . 3 4 8}^{* * *} \\
(0.441)\end{array}$ \\
\hline Coordination & $\begin{array}{l}0.230 \\
(0.229)\end{array}$ & $\begin{array}{c}0.344 \\
(0.314)\end{array}$ & $\begin{array}{c}0.132 \\
(0.132)\end{array}$ & $\begin{array}{l}0.378 \\
(0.425)\end{array}$ \\
\hline Year Enacted & $\begin{array}{c}-0.009^{*} \\
(0.005)\end{array}$ & $\begin{array}{c}-0.011 \\
(0.008)\end{array}$ & $\begin{array}{c}-\mathbf{0 . 0 0 8} * * \\
(0.004)\end{array}$ & $\begin{array}{c}-\mathbf{0 . 0 1 9} \mathbf{c}^{* *} \\
(0.009)\end{array}$ \\
\hline Prior Authority & $\begin{array}{c}0.009 \\
(0.077)\end{array}$ & $\begin{array}{c}0.006 \\
(0.094)\end{array}$ & $\begin{array}{c}0.071 \\
(0.047)\end{array}$ & $\begin{array}{c}0.220 \\
(0.136)\end{array}$ \\
\hline $\begin{array}{l}\text { Net Marginal } \\
\text { Effect of Pub. }\end{array}$ & $\begin{array}{l}-.844^{* * * *} \\
(.232)\end{array}$ & & $\begin{array}{l}-.683 * * * \\
(.173)\end{array}$ & \\
\hline $\begin{array}{l}\text { Net Marginal } \\
\text { Effect of Pub. } \\
\text { Choice, Rival=1 }\end{array}$ & $\begin{array}{c}-.232 \\
(.508)\end{array}$ & & $\begin{array}{c}-.074 \\
(.804)\end{array}$ & \\
\hline R-squared & 0.61 & & .68 & \\
\hline
\end{tabular}

Notes:

Standard errors in (parentheses). OLS estimates with robust standard errors. Controls include DW-nominate scores on dimensions one and two for Senate and House majority party and median. "Net marginal effects" reports the sum of the coefficients for public choice and rival x public choice variables when rival takes each indicated value, with standard errors calculated using the margins command in Stata14.

*: Statistically significant at the $10 \%$ level. **: Statistically significant at the $5 \%$ level.

***: Statistically significant at the $1 \%$ level. N: 85 . 
Congress alters state taxing power, if the state tax falls on a concentrated interest group (while providing undifferentiated revenue benefits to the whole population of the state), Congress is considerably more likely to limit that tax. This finding was statistically significant at the 1 percent level.

As predicted, concentrated interest groups in opposition tend to weaken the influence of interest-group lobbying. However, the impact of these public choice factors is considerably diminished in the presence of rival groups. In the presence of interaction terms, the true marginal effect of one of the factors in the interaction is the sum of the main effect (the coefficient of the variable standing alone) and the coefficient on the interaction term, conditional on the value of the other factor (Brambor et al. 2006). In my set-up, in other words, the true marginal effect of the public choice variable is the sum of $\beta_{1}+\beta_{3}$ Rival $_{i}$. These values are reported for the OLS regressions in the bottom rows of Table 1.2. ${ }^{14}$ When the Rival variable is zero, the net public choice effect is negative and significant. When rival interests are present, however, it is still negative but small and not statistically significant. This combination of outcomes supports the hypothesis that contrary concentrated private lobbying interests can block rent-seeking tax legislation.

For ordered choice variables, the net marginal effect can vary with the outcome, making summary in tabular form difficult. Figure 1.3, below, depicts the impact of the interaction of the rival and public choice variables for the ordered probit regression in which relative scores are coded from one to seven (although there are no observations of a score of seven in the sample). The point estimates are reporting the impact of the public choice variable on the probability of a given relative change in tax restrictions, conditional on the presence of rivals. Point estimates on the left border of the figure are for Rival=0, while the right border estimates are for Rival=1. We see that the relative scores on the right-hand side of the figure are clustered much more closely around zero, suggesting that the presence of rivals considerably diminishes the impact of interest group lobbying. For example, the top line shows the likelihood of a relative score of three, a small increase in tax restrictions, dropping considerably when rivals are present.

Additionally, when I control for other factors I continue to find that whether a statute affects Indian tribes has a highly significant positive effect on the relative score. As reported in Table 1.2, statutes affecting

14 I compute these values and their standard errors using the margins command in Stata14. 


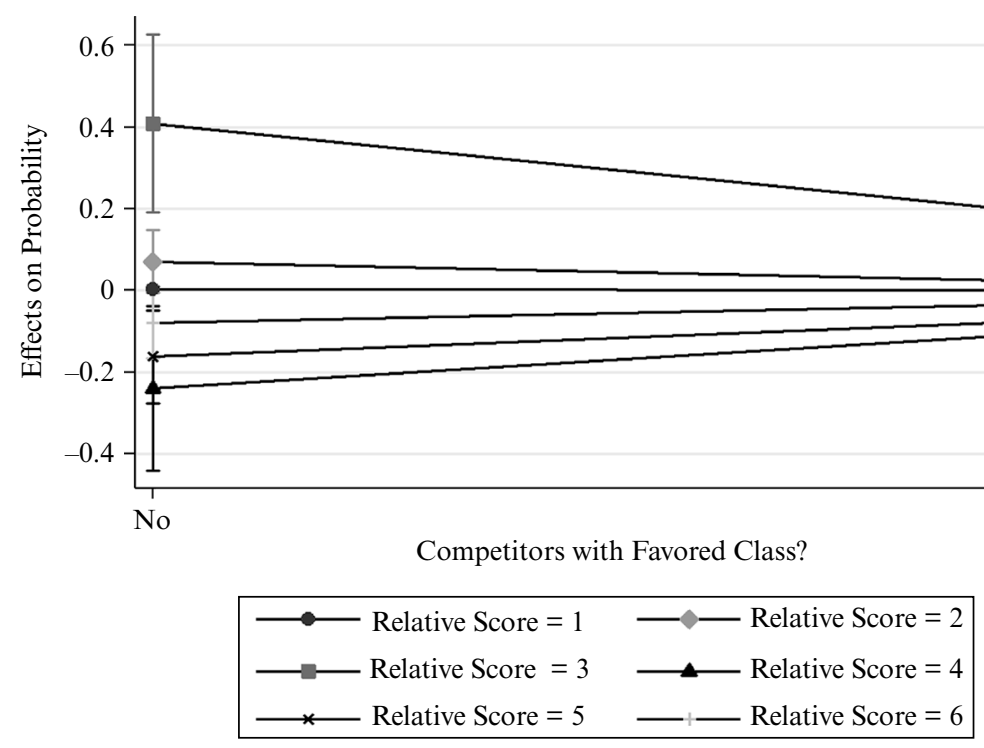

Figure 1.3 Marginal effects of public choice, conditional on rival

Indian tribes on average have considerably higher relative scores than others. Although the confidence intervals are fairly wide, I find a p-value of less than .01 in all of the models. Subject to some caveats, as discussed below, I interpret this finding as evidence in support of both the basecompetition hypothesis as well as the notion that Congress is sensitive to budget pressure.

Other efforts to evaluate the base-competition hypothesis were less successful. I find that measures of Congress' need for funds, such as annual deficit, generally have the predicted negative sign (that is, I find that larger deficits result in greater state restrictions) but are not statistically significant. It may be that my measures are poor proxies for Congressional need for funds, or that I lack enough observations to use those measures meaningfully. Alternately, it may simply be that Congress' need for funds is not an important driver of its state-tax policy.

I do, however, find additional evidence bearing on the budget-pressure question. Congress is less restrictive of state authority as the size of the House increases. ${ }^{15}$ Again, if Levinson (2005) is correct that members of Congress treat the budget as a commons, then we should expect to see

15 Since House size trends monotonically upwards, it is possible this result reflects some secular trend, rather than the effect of House size. I do, however, 
fewer restrictions on competing state revenue sources when the legislative chamber expands and each member internalizes a smaller fraction of each budget-related decision. My results are consistent with that story. The fact that I find variation, though, suggests that Levinson somewhat overstates his case: the commons problem diminishes legislative sensitivity to budget pressure, but this effect varies with chamber size rather than being stuck at a uniform zero sensitivity. And, again, my basecompetition result implies that Congress does appear to care about its revenue stream.

Additionally, I find the expected results for the political controls (not tabulated). The ideology of the dominant party affects to a statistically significant degree decisions to curtail state autonomy, especially ideological views on "states' rights" related race questions. The ideology of the minority party - represented in my data by the chamber median ${ }^{16}$ - points in the opposite direction of the majority party, and the impact of this effect is more pronounced in the Senate.

Finally, I find some evidence that time matters. There is a fairly straight negative linear relation between relative score and year, at least for the period 1900 to present, although in the one to seven specifications this result is only marginally significant in the OLS model and not significant at all in the ordered probit.

\section{INTERPRETATION AND CAVEATS}

Overall, these findings suggest that political self-interest plays a role in Congress' regulation of the states' power to tax. When states seek to tax Indian tribes, who are not sources of revenue for Congress, Congress is considerably more forgiving. And unopposed interest groups fare rather better than others in winning congressional protection, implying that state lobbying can be overcome by interest-group pressure. Indeed, when Congress acts with regard to state tax power, the mean result is a moderate reduction in that power.

One potential concern with these findings is that they could be artifacts of the research design. For example, it might be argued that I find a negative trend in the relative score variable simply because Congress is acting

also control for simple time trends, which should soak up some portion of any unobservable changes in congressional practices.

16 When the controlling party and chamber median positions are included together as explanatory variables, the coefficient of each represents the effects of that variable holding the other constant. 
against a baseline of no or few restrictions, leaving more room in the downward direction.

In my view this is only a minor concern, for several reasons. For one, as noted I restricted the sample to statutes for which there was a pre-existing restriction - that is, where the absolute score of the prior authority was less than seven. By definition, then, every observation in the dataset offered Congress at least some opportunity to relax restrictions as well as to tighten them. ${ }^{17}$ The reported results also include a control for the absolute score of the prior authority; adding this control reduces somewhat the impact of the Indian dummy but does not otherwise affect the outcome. Thus, the restrictiveness of the prior restraint is not a significant predictor of Congress' subsequent behavior. Further, most observed reductions in state authority were by a relatively small amount, which implies that even for statutes with fairly unrestrictive prior authorities there was at least equal room for an equivalent move in the other direction.

Of course, by limiting the dataset to instances where a prior authority, usually the Supreme Court, had already found it necessary to rein in states, I may have introduced selection bias. Of greatest concern is the possibility that the results support the alternative hypothesis that Congress is maximizing national welfare by prohibiting inefficient state taxation. Arguably, subjects of taxation already restricted by the Supreme Court are more likely to be inefficient than others. On the other hand, it could be argued that rules already policed by the Court would need no further oversight by Congress. ${ }^{18}$ In any event, to account for these possibilities, I also coded each enactment for efficiency, a dummy variable. ${ }^{19}$ I find

17 There were no observations in the sample with a prior authority absolute score of 1 , either.

18 Yet another possible reason to expect correlation between Supreme Court decisions and later congressional action is that both are essentially driven by interest groups, who provide resources both for litigation leading to judicial resolution as well as the ensuing legislation (Collins 2007, Staudt et al. 2007). This alternative, though, actually supports my hypothesis that interest-group influence drives commerce-clause outcomes.

19 Since all tax reduction tends towards efficiency in the sense that it reduces deadweight loss, I coded a statute as efficient if its enactment could arguably cure some inefficiency other than the excess burden of taxation. In some cases I balanced pro-efficiency gains against inefficiency losses. Admittedly, some of these scores could be disputed. For example, the Internet Tax Freedom Act bars states from forcing internet service providers to collect sales and use taxes. Arguably this is efficient in the sense that ISPs may generate network externalities, and so subsidies for the industry may be warranted under classic public finance theory. But at the same time this rule results in large geographical distortions, since it permits retailers to escape tax if they have no physical presence in a taxing jurisdiction. 
that efficiency, if anything, is correlated with fewer restrictions on state authority. ${ }^{20}$ Including efficiency as an explanatory variable changes slightly the coefficients of the other variables but does not affect their sign. Additionally, I find no statistically significant difference in the absolute scores of observations within the restricted dataset and those in the dataset as a whole.

Another form of selection bias that I indisputably face is that I can observe only legislation that actually passed. It is possible that states routinely defeat much larger threats to their taxing power than those observed, or that defeated proposals otherwise differ systematically from those in my dataset. Thus, my results are best characterized as describing the common features of enacted legislation, rather than of the legislative process as a whole. Accordingly, I cannot say that political safeguards of federalism are never effective; for all we know, they may well be effective 99 percent of the time. States may also be effective lobbyists on behalf of their local interest groups. What I can say is that the safeguards are likely not 100 percent effective at protecting generalized state interests, and that the observed instances of failure match well with theoretical predictions of failure. ${ }^{21}$

Of course, there is already substantial qualitative evidence that Congress at times diminishes state autonomy, such as through preemption, crosscutting conditions on federal grants, and outright commands to states (NCSL 2004). In many cases, though, what may appear to be a restriction

It also distorts the flow of capital between remote and "brick and mortar" businesses. And government could mitigate the geographical distortions while subsidizing the industry just as effectively by using direct cash payments. So I coded the ITFA as inefficient.

20 It appears this correlation is driven mostly by federal immunity. I coded judicial protection of federal contractors and property from state taxation as an inefficient distortion of capital flows towards the tax-favored firms, so that when Congress waived these protections, the result was efficiency-enhancing.

${ }^{21}$ I say that it is only "likely" that states are not 100 percent effective in their lobbying efforts, notwithstanding my results here, because I cannot rule out the alternative that states themselves were the impetus for federal legislation reducing their own taxing power. That seems at best a minor possibility, though, since any story along those lines seems rather strained. It might be argued, for instance, that states whose neighboring, rival state drew large revenues from a particular source, such as oil, might lobby the federal government to cut off that source of comparative advantage. Or states that are subject to significant tax-exporting might seek to close off the exporting at its source (Rose-Ackerman 1981). But neither story fits particularly well with any of the statutes in the sample. It may be that some states have industries that could benefit from favorable tax treatment, but there is no obvious way to disentangle that possibility from the pure public choice story. 
on state autonomy in fact maximizes state well-being overall, just as constraints on individual liberty (such as prohibitions on theft and assault) may increase net personal freedom. (Charles C. Steward Mach. Co. v. Davis, 301 U.S. 548, 587 (1937).) As is well known, federal action can be a mechanism for resolving coordination or other collective-action problems states might otherwise face (Oates 1999, Cooter 2002). Congress, for example, may be a low-transaction-cost venue for Coasean bargaining between those states that create and those that are affected by externalities (Kobayashi \& Ribstein 2007). The existing literature studying federal impositions on states does not clearly distinguish between these two forms of federal enactment. Thus, the extant literature is unclear on whether federal authority actually reduces state autonomy.

This study advances significantly over the prior, qualitative, literature by controlling for the possibility that federal legislation may be state autonomy-enhancing. As noted, I find no correlation between the efficiency of a statute and the direction of change in state power. Additionally, I created another dummy variable, termed "coordination," to identify federal statutes that arguably could be said to resolve some sort of state-level coordination or other collective-action problem (such as a race to the bottom). ${ }^{22}$ I found, however, that there was no correlation between whether a statute solved coordination problems and the direction of change in state authority: the relation between the two was essentially random, and including the coordination variable in the regression analyses did not meaningfully change the coefficient for any other variable. Of course, this does not prove that coordination is not motivating Congress, but the fact that my evidence shows strong support for a public-choice story and no support for a coordination story is suggestive.

My inability to observe failed legislation is less significant for the purely tax-related aspects of my hypotheses. As noted, the contention in the literature is that Congress will outperform courts in safeguarding national well-being against state-level externalities. In order for Congress to carry out that function, it must act (or at least threaten credibly to act). Thus, in testing claims about how Congress performs when it is able to overcome

22 For instance, I coded as "1" federal enactments that established one and only one state to be the exclusive income-taxing jurisdiction for employees of the railroad, bus, air, and shipping industries. These statutes are not necessarily efficient, in that they tend to distort the choice of state residence. The cumulative burdens of compliance and auditing costs, though, are largely an externality for each state (Shaviro 1992), suggesting that in the absence of coordination workers subject to tax in many states might be forced to comply with a confusing array of regimes. 
legislative inertia, it makes sense to focus narrowly on Congress' actual output. Admittedly, I cannot rule out the possibility that even more forceful judicial efforts to prod Congress might result in passage of more benevolent laws than in the past. But the Supreme Court has already employed what look to be significant penalty defaults in an effort to force congressional action, without any effect measurable in this data or otherwise (see Galle 2007a for more discussion).

Moving beyond selection bias concerns, I must acknowledge that there are alternative interpretations for the influence of the Indian variable. Most significantly, it may be that the reason states have a freer hand to tax Indian tribes is because the tribes are politically weaker than other interest groups affected in the data set. Scholars of U.S.-tribal relations argue that states used tax law, and especially the power to seize the property of tax debtors, as a tool for pillaging tribal property (Taylor 2007). If this were the story, we might perhaps expect a trend towards parity in the modern era as outright oppression faded. I do not, however, observe a significant difference in the time trends between statutes affecting the tribes and others. ${ }^{23}$ Another factor that supports my explanation over this alternative is that, for the alternative to be true, it would have to be the case that Indian tribes are even less effective than the general public at lobbying. But I find to the contrary that the mean relative score for Indian statutes does not differ significantly from the mean for non-Indian, non-public choice statutes; Congress treats tribes roughly the same as the public at large.

Another aspect of the data worth some comment is the frequency with which Congress appears to enact legislation that does not change existing law. Given the difficulty of enacting legislation, that is somewhat puzzling. Staudt et al. (2007) offer several explanations, such as the possibility that legislation expands a judicial decision to new contexts (which I do not observe in my data) or clarifies a confusing precedent. I would further hypothesize that clear notice to the public is valuable in its own right, especially in eras that lack easy access to judicial decisions or computerized searches. I continue to observe in my data simple codification in modern statutes, however, which inclines me towards other explanations. Codification locks in outcomes against possible changes in judicial personnel, and may also, as Staudt et al. (2007) hint at, allow for rent-extraction from constituencies which are relatively unsophisticated about current law. Thus, the extensive codification efforts seen in the data here provide some additional evidence of rent-seeking behavior by Congress.

23 Interactions of the year term with the Indian variable also yielded no significant results. 
One final riddle is how to interpret the linear, albeit in some specifications insignificant, negative relationship between year and relative score. Percentages of national government expenditures spent at the state level, as well as attitudes towards federal taxes (Kincaid \& Cole 2007, Kincaid \& Cole 2000), exhibit a similar overall negative trend, while measures of overall policy centralization (Bowman \& Krause 2003) show no correlation with our result. Another possible explanation could be a learning story, in which special interests have over time developed expertise in influencing Congress, or members of Congress have become more aware of the potential for rent-extraction through tax legislation (Posner 2005). I found no significant results with any interaction terms between the year, public choice, and rival variables. Still, this might simply represent the limitations of the data.

\section{CONCLUSION}

While my evidence here certainly does not end any debates over federalism, it is suggestive. Claims that states never need to fear inefficient federal expansions seem likely to be overstated. I find that, at least in the case where special interest influence is strong, and Congress can export the costs of regulation to the States, congressional action in fact does tend to diminish state prerogatives. Further, I find no evidence that this diminution might be serving to preserve state autonomy in the long run by facilitating coordination among states.

I therefore provide at least modest support for a continuing judicial role in federalism decisions. To be sure, the possibility of occasional bad deeds by Congress is not the only factor in play. Unfunded mandates might still be justified as efficient allocation of the social costs of regulation (Dana 1995, Adler 1997, Roin 1999), or shrugged off as simply another opportunity for states to hold up the federal government within a cooperative regime (Caminker 1995, Siegel 2006, Bulman-Pozen \& Gerken 2009). And courts may simply be so bad at federalism decisions that even a Congress that can at times be captured by special interests looks good by comparison. In some areas, however, such as the dormant commerce clause, commentary to date has assumed uncritically that Congress is both the superior fact-finder and also a trustworthy maximizer of national welfare. At a minimum, my findings here warrant consideration of how to balance the strengths and weaknesses of the three branches in regulating free trade, a project I take up elsewhere.

In addition, my results shed some light on the motivations of Congress. Levinson (2005) argues that members of Congress are at best only weakly 
motivated by the size of the federal budget, since the effect of any one actor on the budget as a whole is largely an externality for individual members. I find, in contrast, that opportunities for reducing budget pressure do seem to play a role at least in statutes affecting state tax policy. Internal institutional factors, such as party leadership and budget rules, may outweigh the collective action problems members would otherwise face, a possibility that merits further investigation.

Lastly, it is worth emphasizing the institutional dimension of these findings. I study here only Congress and, indirectly, the President as veto player. I have argued elsewhere that administrative agencies are relatively more likely to take care with state autonomy, at least in the case where judicial review demands that they do so (Galle \& Seidenfeld 2008). My results therefore suggest the possible appeal of a federalism doctrine that shifts more authority to agencies, although more empirical work into the performance of the executive is needed to confirm whether in fact agencies function better than Congress.

\section{REFERENCES}

Adler, Robert. 1997. "Unfunded Mandates and Fiscal Federalism: A Critique," 50 Vanderbilt Law Review 1137.

Baker, Lynn A. 1995. "Conditional Federal Spending after Lopez," 95 Columbia Law Review 1911.

Baker, Lynn A. \& Ernest A. Young. 2002. "Federalism and the Double Standard of Judicial Review," 51 Duke Law Journal 75.

Bednar, Jenna. 2007. "Credit Assignment and Federal Encroachment," 15 Supreme Court Economic Review 285.

Bellia, Anthony J., Jr. 2006. "Congressional Power and State Court Jurisdiction," 94 Georgetown Law Journal 949.

Bowman, Ann O’M. \& George A. Krause. 2003. "Power Shift: Measuring Policy Centralization in U.S. Intergovernmental Relations, 1947-1998," 31 American Politics Research 301.

Brambor, Thomas, William Roberts Clark, \& Matt Golder. 2006. "Understanding Interaction Models: Improving Empirical Analysis,” 14 Political Analysis 63.

Brennan, Geoffrey \& Buchanan, James. 1984. "Towards a Tax Constitution for Leviathan," in The Theory of Public Choice II. Ann Arbor: University of Michigan Press.

Bulman-Pozen, Jessica \& Heather K., Gerken. 2009. "Uncooperative Federalism," 118 Yale Law Journal 1256.

Caminker, Evan. 1995. "State Sovereignty and Subordinacy: May Congress Commandeer State Officials to Implement Federal Law?" 95 Columbia Law Review 1001.

Carroll, Royce et al. 2011. "DW-Nominate Scores with Bootstrapped Standard Errors." http://www.voteview.com/dwnomin.htm.

Carroll, Royce et al. 2008. "Measuring Bias and Uncertainty in DW-Nominate 
Ideal Point Estimates Using the Parametric Bootstrap.” Working Paper. http:// papers.ssrn.com/sol3/papers.cfm?abstract_id=1281667.

Choper, Jesse H. 1980. Judicial Review and the National Political Process: A Functional Reconsideration of the Role of the Supreme Court. Chicago: Chicago University Press.

Collins, Paul M., Jr. 2007. "Towards an Integrated Model of the U.S. Supreme Court's Federalism Decision Making," 37 Publius: The Journal of Federalism 505.

Cooter, Robert. 2002. The Strategic Constitution. Princeton: Princeton University Press.

Dana, David. 1995. "The Case for Unfunded Environmental Mandates," 69 Southern California Law Review 1.

Derthick, Martha. 1986. "Preserving Federalism: Congress, the States, and the Supreme Court," The Brookings Review Winter/Spring: 32.

Dinan, John. 2009. "The State of American Federalism 2007-2008,” 38 Publius 381.

Dinan, John. 1997. "State Government Influence in the National Political Process: Lessons from the 104th Congress," 27 Publius 129.

Eule, Julian N. 1982. "Laying the Dormant Commerce Clause to Rest," 91 Yale Law Journal 425.

Frickey, Philip P. 1990. "Congressional Intent, Practical Reasoning, and the Dynamic Nature of Federal Indian Law," 78 California Law Review 1137.

Galle, Brian. 2013. "The Effects of National Revenues on Sub-National Revenues: Evidence from the United States," 37 International Review of Law \& Economics 147.

Galle, Brian. 2008. "Federal Grants, State Decisions," 88 Boston University Law Review 875.

Galle, Brian. 2007a. "Designing Interstate Institutions: The Example of the Streamlined Sales and Use Tax Agreement," 40 U.C. Davis Law Review 1381.

Galle, Brian. 2007b. "A Republic of the Mind: Cognitive Biases, Fiscal Federalism, and Section 164 of the Tax Code," 82 Indiana Law Journal 673.

Galle, Brian. 2004."Getting Spending: How to Replace Clear Statement Rules with Clear Thinking about Conditional Grants of Federal Funds," 37 Connecticut Law Review 155.

Galle, Brian \& Mark Seidenfeld. 2008. "Administrative Law's Federalism: Preemption, Delegation, and Agencies at the Edge of Federal Power," 57 Duke Law Journal 1933.

Garrett, Elizabeth. 1997. "Enhancing the Political Safeguards of Federalism: The Unfunded Mandates Reform Act of 1995," 45 University of Kansas Law Review 1113.

Hamilton, Marci A. 2001."The Elusive Safeguards of Federalism," 574 Annals of the American Academy of Political and Social Science 93.

Hanson, I. \& Stuart, C. 1987. "The Sub-Optimality of Local Taxation under Two-Tier Fiscal Federalism," 3 European Journal of Political Economy 407.

Hellerstein, Jerome. 1941. "State Taxation in a National Economy," 54 Harvard Law Review 949.

Hero, Rodney. 1989. "The U.S. Congress and American Federalism: Are 'Subnational Governments' Protected?” 42 Western Political Quarterly 93.

Hills, Roderick M., Jr. 1998. "The Political Economy of Cooperative Federalism: Why State Autonomy Makes Sense and 'Dual Sovereignty' Doesn't," 96 Michigan Law Review 813. 
Jensen, Erik M. 2008. "Indian Gaming on Newly Acquired Lands," 47 Washburn Law Journal 675.

Jones, Renee M. 2004."Dynamic Federalism: Competition, Cooperation and Securities Enforcement,” 11 Connecticut Insurance Law Journal 1.

Joondeph, Brad. 2003. "Exploring the 'Myth of Parity' in State Taxation: State Court Decisions Interpreting Public Law," 13 Washington University Journal of Law and Policy 86-272.

Kagan, Elena. 2001. "Presidential Administration," 114 Harvard Law Review 2245.

Kam, Cindy D. \& Robert A. Mikos. 2007. "Do Citizens Care about Federalism? An Experimental Study," 4 Journal of Empirical Legal Studies 589.

Keele, Luke \& David K. Park. 2006. "Difficult Choices: An Evaluation of Heterogeneous Choice Models," unpublished working paper.

Kincaid, John \& Richard L. Cole. 2007. "Public Opinion on Issues of Federalism in 2007: A Bush Plus?” 38 Publius: The Journal of Federalism 469.

Kincaid, John \& Richard L. Cole. 2000. "Public Opinion and American Federalism: Perspectives on Taxes, Spending, and Trust-An ACIR Update," 30 Publius: The Journal of Federalism 189.

Klick, Jonathan \& Francesco Parisi. 2005. "Intra-Jurisdictional Tax Competition," 16 Constitutional Political Economy 387.

Kobayashi, Bruce H. \& Larry E. Ribstein. 2007. "Introduction," in Economics of Federalism. Northampton: Edward Elgar Press.

Kramer, Larry. 2000. "Putting the Politics Back into the Political Safeguards of Federalism," 100 Columbia Law Review 215.

La Pierre, D. Bruce. 1985. "Political Accountability in the National Political Process - The Alternative to Judicial Review of Federal Issues," 80 Northwestern University Law Review 577.

Lee, Carol. 1988. "The Political Safeguards of Federalism?: Congressional Responses to Supreme Court Decisions on State and Local Liability," 20 Urban Lawyer 301.

Levinson, Daryl J. 2005. "Empire-Building Government in Constitutional Law," 118 Harvard Law Review 915.

Macey, Jonathan R. 1986."Promoting Public-Regarding Legislation through Statutory Interpretation: An Interest-Group Model," 86 Columbia Law Review 223.

Mayhew, David. 1974. Congress: The Electoral Connection. New Haven: Yale University Press.

McCaffrey, Edward J. \& Jonathan Barron. 2006. "Thinking about Tax," 12 Psychology, Public Policy, and Law 106.

McGinnis, John O. 2001. "Presidential Review as Constitutional Restoration," 51 Duke Law Journal 901.

McGinnis, John O. \& Ilya Somin. 2004. "Federalism vs. States' Rights: A Defense of Judicial Review in a Federal System," 99 Northwestern University Law Review 89

Mendelson, Nina A. 2004. "Chevron and Preemption," 102 Michigan Law Review 737.

Metzger, Gillian. 2008. "Administrative Law as the New Federalism," 57 Duke Law Journal 2023.

Metzger, Gillian. 2007. "Congress, Article IV, and Interstate Relations," 120 Harvard Law Review 1468. 
National Conference of State Legislatures. 2004. Mandate Monitor. Washington, DC: NCSL.

Nicholson-Crotty, Sean. 2008. "National Election Cycles and the Intermittent Political Safeguards of Federalism," 38 Publius: The Journal of Federalism 295.

Nzelibe, Jide. 2006. "The Fable of the Nationalist President and the Parochial Congress," 53 UCLA Law Review 1217.

Oates, Wallace. 1999. "An Essay on Fiscal Federalism," 37 Journal of Economic Literature 1120.

Olson, Mancur. 1982. The Rise and Decline of Nations. New Haven: Yale University Press.

Pickerill, J. Mitchell. 2004. The Impact of Judicial Review in a Separated System. Raleigh: Duke University Press.

Posner, Paul. 2005. "The Politics of Preemption," 38 PS: Political Science and Politics 371.

Pursley, Garrick B. 2010. "Preemption in Congress," 71 Ohio State Law Journal 511.

Redish, Martin H. \& Nugent, Shane V. 1987. "The Dormant Commerce Clause and the Constitutional Balance of Federalism," 1987 Duke Law Journal 569.

Resnik, Judith. 2008. "Lessons in Federalism from the 1960s Class Action Rule and the 2005 Class Action Fairness Act: 'The Political Safeguards' of Aggregate Translocal Actions," 156 University of Pennsylvania Law Review 1929.

Roin, Julie A. 1999. "Reconceptualizing Unfunded Mandates and Other Regulations," 93 Northwestern University Law Review 351.

Rose-Ackerman, Susan. 1981. "Does Federalism Matter? Political Choice in a Federal Republic," 89 Journal of Political Economy 152.

Rubin, Edward L. \& Feeley, Malcolm. 1994. "Federalism: Some Notes on a National Neurosis," 41 UCLA Law Review 903.

Sharkey, Katherine M. 2008. "Products Liability Preemption: An Institutional Approach," 76 George Washington University Law Review 449.

Shaviro, Daniel. 1992. "An Economic and Political Look at Federalism in Taxation," 90 Michigan Law Review 895.

Siegel, Neil S. 2006. "Commandeering and its Alternatives: A Federalism Perspective," 59 Vanderbilt Law Review 1629.

Solberg, Rorie S. \& Stefanie A. Lindquist. 2006. "Activism, Ideology, and Federalism: Judicial Behavior in Constitutional Challenges before the Rehnquist Court, 1986-2000," 3 Journal of Empirical Legal Studies 237.

Staudt, Nancy, Rene Lindstadt, \& Jason O'Connor. 2007. "Judicial Decisions as Legislation: Congressional Oversight of Supreme Court Tax Cases, 1954-2005," 82 New York University Law Review 1340.

Swain, John A. 2003. "States Sales and Use Tax Jurisdiction: An Economic Nexus Standard for the Twenty-First Century," 38 Georgia Law Review 343.

Taylor, Scott A. 2007. "A Judicial Framework for Applying Supreme Court Jurisprudence to the State Income Taxation of Indian Traders," 2007 Michigan State Law Review 841.

Tribe, Laurence. 1999. American Constitutional Law: Volume One, 3rd edn. New York: Foundation Press.

Wechsler, Herbert. 1954. "The Political Safeguards of Federalism: The Role of States in the Composition and Selection of the National Government," 54 Columbia Law Review 543. 
Weissert, Carol S. \& Sanford F. Schram. 1996. "The State of American Federalism, 1995-1996," 26 Publius: The Journal of Federalism 1.

Zelinsky, Edward. 2002. "Restoring Politics to the Commerce Clause: The Case for Abandoning the Dormant Commerce Clause Prohibition on Discriminatory Taxation," 29 Ohio Northern Law Review 29.

Zelinsky, Edward. 1993. "Unfunded Mandates, Hidden Taxation, and the Tenth Amendment: On Public Choice, Public Interest, and Public Services," 46 Vanderbilt Law Review 1355. 